\title{
Bio-ethanol production through simultaneous saccharification and co-fermentation (SSCF) of a low-moisture anhydrous ammonia (LMAA)-pretreated napiegrass (Pennisetum purpureum Schumach)
}

\author{
Masahide Yasuda ${ }^{1 *}$, Hayato Nagai ${ }^{1}$, Keisuke Takeo ${ }^{1}$, Yasuyuki Ishii ${ }^{2}$ and Kazuyoshi Ohta ${ }^{3}$
}

\begin{abstract}
Efficient bio-ethanol production from napiegrass (Pennisetum purpureum Schumach) was investigated. A low-moisture anhydrous ammonia (LMAA)-pretreated napiegrass was subjected to simultaneous saccharification and co-fermentation (SSCF), which was performed at $36^{\circ} \mathrm{C}$ using Escherichia coli KO11, Saccharomyces cerevisiae, cellulase, and xylanase. It was found that use of xylanase as well as the LMAA-pretreatment was effective for the SSCF. After the SSCF for $96 \mathrm{~h}$, the ethanol yield reached $74 \%$ of the theoretical yield based on the glucan (397 $\mathrm{mg} \mathrm{g}^{-1}$ ) and xylan (214 $\mathrm{mg} \mathrm{g}^{-1}$ ) occurring in dry powdered LMAA-pretreated napiergrass.
\end{abstract}

Keywords: Bio-ethanol; Simultaneous saccharification and co-fermentation (SSCF); Napiergrass; Cellulase; Xylanase; Escherichia coli KO11; LMAA-pretreatment

\section{Introduction}

Bioethanol from lignocellulosic biomass has been recognized as one of promising sustainable energy source alternative to petroleum-based fuels, since the lignocelluloses are not directly in competition with food sources (Galbe and Zacchi 2007; Taherzadeh and Karimi 2007). We are interested in ethanol production from herbaceous lignocellulosic napiergrass (Pennisetum purpureum Schumach) because of its low lignin content and high harvest amount per year and per area (Yasuda et al. 2012, 2013). In lignocellulosic ethanol production, pentose fermentation is an unavoidable process because of its high xylan content. In pentose fermentation process, however, ethanol concentration is usually too low $\left(<10 \mathrm{~g} \mathrm{~L}^{-1}\right)$ to distillate with low energy cost. Therefore, pentose fermentation has been performed as co-fermentation of hexose and pentose using a variety of recombinant strains such as Escherichia coli KO11 (Ohta et al. 1990, 1991; Underwood et al. 2002;

\footnotetext{
* Correspondence: yasuda@cc.miyazaki-u.ac.jp

${ }^{1}$ Department of Applied Chemistry, Faculty of Engineering, University of

Miyazaki, Gakuen-Kibanadai Nishi, Miyazaki 889-2192, Japan

Full list of author information is available at the end of the article
}

Brandon et al. 2011), Saccharomyces cerevisiae 424A (LNH-ST) (Jin et al. 2012a, b), S. cerevisiae TMB3400 (Ohgren et al. 2006; Matsushika et al. 2009), and Zymomonas mobilis AX101 (Su et al. 2012). Simultaneous saccharification and co-fermentation (SSCF) is generally superior to the separate saccharification and co-fermentation since SSCF can achieve saccharification, hexose fermentation, and pentose fermentation in one-pot reaction. Here, we applied SSCF to ethanol production from napiergrass, which was treated by low-moisture anhydrous ammonia (LMAA) pretreatment.

\section{Materials and methods}

\section{Napiergrass as lignocellulosic materials}

As raw material, a dwarf type of napiergrass was cultivated in the Kibana Agricultural Science Station, at the University of Miyazaki. Leaf blades of the napiergrass were separated from the stem and then cut by a cutter and dried at $70^{\circ} \mathrm{C}$ for $72 \mathrm{~h}$. The dried matter was ground until $70 \%$ of the particles were in a range of $32-150 \mu \mathrm{m}$ in length. 


\section{Chemical components of napiergrass}

The powdered napiergrass $(30 \mathrm{~g})$ was treated with a $1 \%$ aqueous solution of $\mathrm{NaOH}(400 \mathrm{~mL})$ at $95^{\circ} \mathrm{C}$ for $1 \mathrm{~h}$. The holocellulose was isolated as a pale yellow precipitate by centrifugation and filtration of the treated mixture. The supernatant solution was neutralized to $\mathrm{pH} 5.0$ by a dilute $\mathrm{HCl}$ solution. The resulting dark brown precipitate identified as lignin was collected via centrifugation at 10,000 rpm for $10 \mathrm{~min}$. Sugars in holocellolose were determined according to the methods published by the National Renewable Energy Laboratory as follows (Sluiter et al. 2010). Sulfuric acid (72 wt\%, $3.0 \mathrm{~mL}$ ) was added slowly to holocelulose $(300 \mathrm{mg})$ and kept at $30^{\circ} \mathrm{C}$ for $1 \mathrm{~h}$. The resulting solution was diluted by water $(84 \mathrm{~mL})$ until the concentration of sulfuric acid was $4 \mathrm{wt} \%$. Acid hydrolysis was performed by autoclaving at $121^{\circ} \mathrm{C}$ for $1 \mathrm{~h}$ in an autoclave. After the neutralization by $\mathrm{CaCO}_{3}$, the solution was subjected to the centrifugation to give the supernatant solution (ca. $87 \mathrm{~mL}$ ), which was concentrated to $30 \mathrm{~mL}$ by evaporation. The solution was analyzed by HPLC. The peaks of glucose and xylose appeared whereas the peaks of galactose and arabinose were very weak because of their low contents. The amounts of glucan and xylan were determined from the amounts of glucose and xylose determined by HPLC. It was confirmed that the sum amounts of glucan and xylan were equaled to the amounts of hollocellolose. The ash component in lignocellulose was obtained by the burning of the lignocellulose $(2.0 \mathrm{~g})$ in an electric furnace (KBF784N1, Koyo, Nara, Japan) for $2 \mathrm{~h}$ at $850^{\circ} \mathrm{C}$.

\section{Low-moisture anhydrous ammonia (LMAA) pretreatment}

Water (100 g) was added dropwise to dry powdered napiergrass $(100 \mathrm{~g}$, volume $320 \mathrm{~mL})$ in the flask $(1 \mathrm{~L})$. The resulting moist powdered napiergrass in the flask was evacuated with a pump under $20 \mathrm{~mm} \mathrm{Hg}$ and then gaseous $\mathrm{NH}_{3}$ was introduced into the flask. This operation was performed three times until the atmosphere inside the flask was entirely replaced with $\mathrm{NH}_{3}$. The amount of $\mathrm{NH}_{3}$ presented in the flask was $1.1 \mathrm{~g}$. The LMAA pretreatment was performed by modifying the Kim method where LMAA pretreatment was performed at $80^{\circ} \mathrm{C}$ for $86 \mathrm{~h}$ (Yoo et al. 2011). In our LMAA-pretreatment, the moist powdered napiergrass was kept under $\mathrm{NH}_{3}$ gas atmosphere at room temperature for four weeks ( 28 days). After the treatment, the $\mathrm{NH}_{3}$ was removed with an evaporator. The treated napiergrass was washed with water $(2 \mathrm{~L})$ three times to separate the brownish aqueous solution of the lignin. After $\mathrm{pH}$ was checked to be neutral, the pretreated napiergrass was dried at $60^{\circ} \mathrm{C}$ to weigh out the precise amount of napiergrass in the following biological treatment.

\section{Hydrolytic enzyme for saccharification}

A cellulase from Acremonium cellulolyticus (Acremozyme KM, Kyowa Kasei, Osaka, Japan) was selected by comparing its activity with other cellulases such as Meycellase (Meiji Seika), a cellulase from Trichoderma viride (Wako Chemicals, Osaka, Japan) and a cellulase from Aspergillus niger (Fluka Japan, Tokyo) (Yasuda et al. 2011). The cellulase activity of Acremozyme KM was determined to be 1,320 units $\mathrm{mg}^{-1}$ by the method of breaking down filter paper (Kitamikado and Toyama 1962). A xylanases from Trichoderma longibrachiatum (reesei) (Sumizyme X, Shin Nihon Chemicals, Anjyo, Japan, 5,000 u g ${ }^{-1}$ ) was selected from commercially available hemicellulase.

Saccharification was performed for the powdered napiergrass $(10.0 \mathrm{~g})$ using both cellulase and xylanase, whose total amount was $1.0 \mathrm{~g}$, at $45^{\circ} \mathrm{C}$ in an acetate buffer (60 mL, pH 5.0).

\section{Preparation of the inoculum culture of Escherichia coli KO11 and Saccharomyces cerevisiae}

E. coli KO11 was grown in the LB medium $(200 \mathrm{~mL})$ consisting of tryptone $\left(2.0 \mathrm{~g} \mathrm{~L}^{-1}\right.$, Difco), yeast extract (1.0 g $\left.\mathrm{L}^{-1}\right)$, and $\mathrm{NaCl}\left(2.0 \mathrm{~g} \mathrm{~L}^{-1}\right)$ under shaking at $150 \mathrm{rpm}$ at $37^{\circ} \mathrm{C}$ for $24 \mathrm{~h}$. The $\mathrm{KO} 11$ cell suspension contained a dry weight of $0.52 \mathrm{mg} \mathrm{mL}^{-1}$ of E. coli KO11. Saccharomyces cerevisiae NBRC 2044 was grown at $30^{\circ} \mathrm{C}$ for $24 \mathrm{~h}$ in a basal medium (initial $\mathrm{pH} 5.5)$ consisting of glucose (20.0 g $\left.\mathrm{L}^{-1}\right)$, polypeptone $\left(1.0 \mathrm{~g} \mathrm{~L}^{-1}\right)$, yeast extract $\left(1.0 \mathrm{~g} \mathrm{~L}^{-1}\right)$, $\mathrm{KH}_{2} \mathrm{PO}_{4}\left(1.0 \mathrm{~g} \mathrm{~L}^{-1}\right)$, and $\mathrm{MgSO}_{4}\left(3.0 \mathrm{~g} \mathrm{~L}^{-1}\right)$. After incubating for $24 \mathrm{~h}$, the cell suspension of $S$. cerevisiae, whose grown culture of $S$. cerevisiae showed a cell density of $7.7 \times 10^{7}$ cells $\mathrm{mL}^{-1}$, was obtained (Yasuda et al. 2012).

\section{Simultaneous saccharification and co-fermentation (SSCF)}

Typical procedure of SSCF is as follows. The LMAApretreated napiergrass $(3.0 \mathrm{~g})$ was suspended in the acetate buffer $(14.0 \mathrm{~mL}, \mathrm{pH} 5.0)$ and then autoclaved at $121^{\circ} \mathrm{C}$ for $20 \mathrm{~min}$. After cooling to room temperature under UVirradiation, the cell suspension $(0.36 \mathrm{~mL})$ of $S$. cerevisiae, a portion $(21 \mathrm{~mL})$ of the inoculum culture E. coli KO11, and the cellulase $(150 \mathrm{mg})$ and xylanase $(150 \mathrm{mg})$ in an acetate buffer solution $(5.0 \mathrm{~mL}, \mathrm{pH} 5.0)$ were added to the suspension of the napiergrass. After $\mathrm{pH}$ was adjusted to 6.0, air was purged with $\mathrm{N}_{2}$. In the SSCF without S. cerevisiae, replacement by $\mathrm{N}_{2}$ gas was not performed. The SSCF was initiated by stirring the solution vigorously with a magnetic stirrer at $36^{\circ} \mathrm{C}$ which was an optimal fermentation temperature of E. coli $\mathrm{KO} 11$. The evolved $\mathrm{CO}_{2}$ was collected over water by a measuring cylinder, and the reaction was monitored by the volume of $\mathrm{CO}_{2}$. The SSCF reaction was continued for $96 \mathrm{~h}$ until $\mathrm{CO}_{2}$ evolution ceased.

\section{Analytical methods}

Saccharides were analyzed on a high-performance liquid chromatography system (LC-20AD, Shimadzu, Kyoto, 
Japan) equipped with RI detector (RID-10A) using an anion exchange column (NH2P-50 4E; Shodex Asahipak, $250 \mathrm{~mm}$ in length and $4.6 \mathrm{~mm}$ in ID, Yokohama, Japan). Acetonitrile-water $(8: 2 \mathrm{v} / \mathrm{v})$ was flowed at $1.0 \mathrm{~mL} \mathrm{~min}{ }^{-1}$ as mobile phase. Ethanol was analyzed by gas-liquid chromatography using 2-propanol as an internal standard on a Shimadzu gas chromatograph GC-8A equipped with a glass column of 5\% Thermon 1000 on Sunpak-A (Shimadzu).

\section{Results and discussion}

\section{Ethanol production from lignocelluloses}

In general, the cellulosic bio-ethanol production involves three steps such as saccharification of cellulosic components (SA), hexose fermentation (HF), and pentose fermentation (PF). These processes are combined each other to simplify the procedure and enhance the ethanol yield. Typical combinations are as follows: SSF is simultaneous process of SA and HF but does not take place PF. CF is co-fermentation of hexose and pentose. SSCF is simultaneous process of SA, HF, and PF. For efficient cellulosic bio-ethanol production, moreover, pretreatment to remove the lignin and/or promote an enzymatic digestibility of the cellulosic components are usually required.

\section{Napiergrass as raw material}

Napiergrass belongs to herbaceous tropical species, native to the east Africa and has high dry matter productivity with moderate forage quality in southern Kyushu (Ishii et al. 2005a, 2013). Napiergrass has wide variation of phenotypes, reflected by plant breeding due to the crossing of dwarf genotype and relative species such as pearl millet (Pennisetum americanum) (Ishii et al. 2005a; Hanna and Sollenburger 2007). A dwarf variety of late-heading type of napiergrass (dwarf napiergrass) originated from Florida, USA, via Thailand (Mukhtar et al. 2003) was assessed to be suitable for both grazing (Ishii et al. 2005b) and cutand-carry systems among several sites of southern Kyushu, Japan (Utamy et al. 2011). Dwarf napiergrass meets the requirement of lignocellulose for the biofuel production because it has low lignin-content and a relatively high herbage mass per year and per area (Rengsirikul et al. 2011; Rengsirikul et al. 2013; Khairani et al. 2013). Therefore, we have continued to use this dwarf type of napiergrass for the bio-ethanol (Yasuda et al. 2011) and biohydrogen production (Shiragami et al. 2012).

As has been reported previously (Yasuda et al. 2013), the LMAA-pretreatment was useful for the simultaneous saccharification and fermentation (SSF) of napiergrass. In the present case, therefore, the powdered napiergrass was subjected to the LMAA-pretreatment. The LMAApretreated napiergrass contained $39.7 \mathrm{wt} \%$ of glucan, $21.4 \mathrm{wt} \%$ of xylan, $7.1 \mathrm{wt} \%$ of lignin, and $7.1 \mathrm{wt} \%$ of ash, while the components of the non-treated napiergrass were determined to be 31.3 (glucan), 16.9 (xylan), 12.6 (lignin), and $13.9 \mathrm{wt} \%$ (ash).

\section{Optimization of enzymatic saccharification}

The effect of LMAA-pretreatment was checked by the enzymatic saccharification. Saccharification of non-treated and LMAA-pretreated napiergrass $(10.0 \mathrm{~g})$ was performed using cellulase (Acremozyme $\mathrm{KM}, 1.00 \mathrm{~g}$ ) at $45^{\circ} \mathrm{C}$ in an acetate buffer $(60 \mathrm{~mL})$. Results are shown in Table 1 . Saccharification of no-treated napiergrass produced the total saccharides in 54\% yield (Table 1 run 1). In the case of napiergrass which was subjected LMAA pretreatments for four weeks, the yield of saccharides was $67 \%$ which was the higher than the cases of LMAA for one and two weeks (runs 2-4). Figure 1 shows the time-conversion of glucose and xylose obtained from the saccharification of the LMAA-pretreated napiergrass. Although the glucose increased rapidly to reach the maximum amounts until $48 \mathrm{~h}$, xylose increased gradually even at saccharification for $360 \mathrm{~h}$. Thus the saccharification of xylan was very slow.

In order to shorten the saccharification time, xylanase (Sumizyme X) was used in addition to cellulase. Xylanase was used in $F_{\mathrm{X}} \times 1.0 \mathrm{~g}$ where $F_{\mathrm{X}}$ was a fraction of xylanase in the mixed enzymes. Figure 2 shows the effect of $F_{\mathrm{X}}$ on the saccharide yields in the saccharification of LMAApretreated napiergrass for $168 \mathrm{~h}$. The optimal $F_{\mathrm{X}}$ value was determined to be 0.50 since the yield of xylose was

Table 1 Saccharification of LMAA-pretreated napiergrass ${ }^{a)}$

\begin{tabular}{lcllll}
\hline Run & PT $^{\mathbf{b})}$ & $\boldsymbol{F}_{\mathbf{X}}{ }^{\mathbf{c}}$ & \multicolumn{3}{c}{ Product/g (yield/\%) } \\
\cline { 4 - 6 } & & & Glucose & Xylose & Total \\
\hline 1 & NO & 0.0 & $2.20(63)$ & $0.68(36)$ & $2.88(54)$ \\
2 & LMAA (1) & 0.0 & $2.89(66)$ & $0.91(38)$ & $3.80(63)$ \\
3 & LMAA (2) & 0.0 & $3.07(70)$ & $1.16(49)$ & $4.23(63)$ \\
4 & LMAA (4) & 0.0 & $3.36(76)$ & $1.20(51)$ & $4.57(67)$ \\
5 & LMAA (4) & 0.3 & $3.23(73)$ & $1.13(48)$ & $4.36(64)$ \\
6 & LMAA (4) & 0.4 & $3.56(81)$ & $1.49(63)$ & $5.05(74)$ \\
7 & LMAA (4) & 0.5 & $4.14(94)$ & $1.60(68)$ & $5.74(85)$ \\
8 & LMAA (4) & 0.6 & $4.25(96)$ & $1.48(62)$ & $5.73(86)$ \\
9 & LMAA (4) & 0.7 & $3.92(90)$ & $1.51(64)$ & $5.43(81)$ \\
10 & LMAA (4) & 0.8 & $3.72(84)$ & $1.47(62)$ & $5.20(78)$ \\
11 & LMAA (4) & 0.9 & $3.63(82)$ & $1.30(55)$ & $4.93(73)$ \\
12 & LMAA (4) & 1.0 & $3.05(69)$ & $0.95(40)$ & $4.00(59)$ \\
\hline
\end{tabular}

a) Saccharification was performed for napiergrass $(10.0 \mathrm{~g})$ using the hydrolytic enzyme $(1.0 \mathrm{~g})$ in an acetate buffer $(60 \mathrm{~mL})$ at $45^{\circ} \mathrm{C}$ for $168 \mathrm{~h}$.

b) Pretreatment (PT). NO: non-treatment. LMAA: a low-moisture anhydrous ammonia pretreatment. The value in parenthesis was the period in week for LMAA- pretreatment.

${ }^{c} F_{\mathrm{X}}$ value was the fraction of xylanase in the mixture $(1.0 \mathrm{~g})$ of cellulase and xylanase.

${ }^{d)}$ The amounts of saccharides obtained from the saccharification of $10 \mathrm{~g}$ of the pretreated napiergrass. 


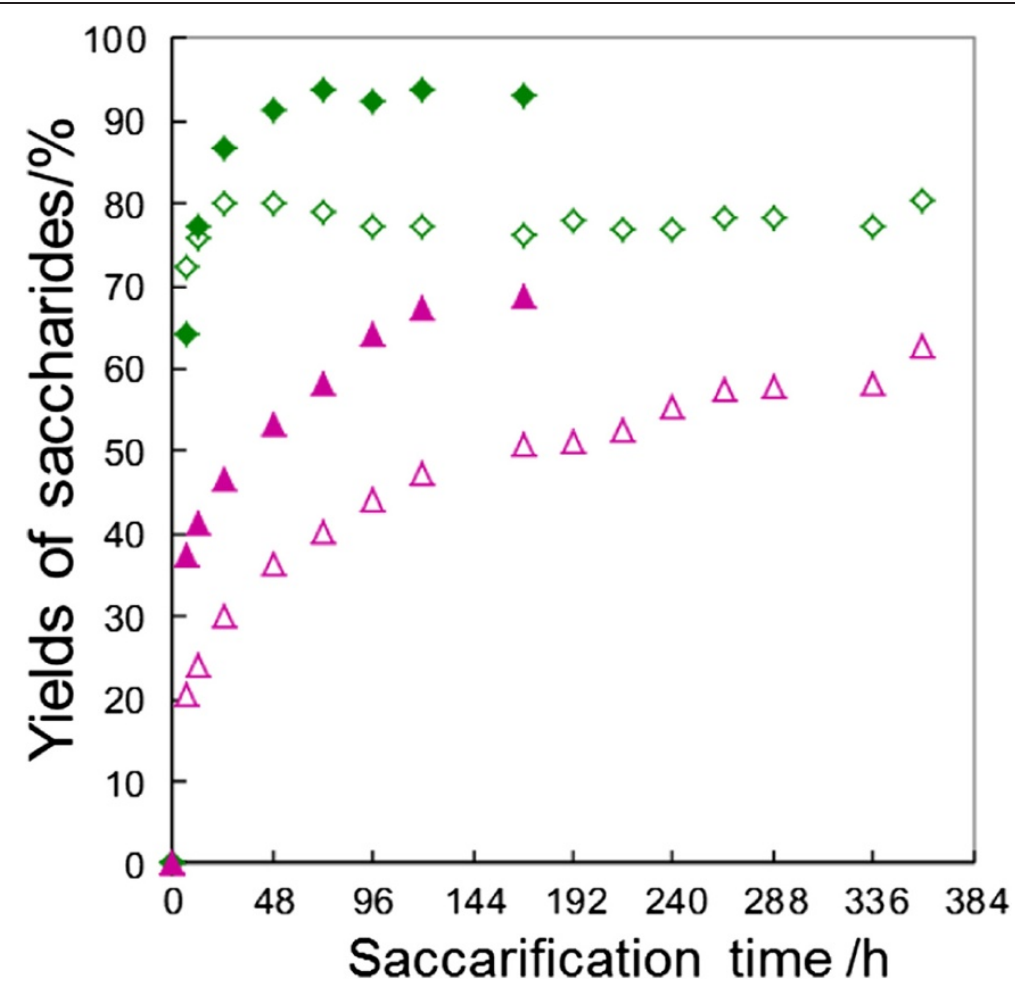

Figure 1 Time-conversion plots of the amounts of glucose and xylose in saccharification of LMAA-pretreated napiergrass (10.0 g) using cellulase and/or xylanase. Glucose $(\bullet)$ and xylose $(\boldsymbol{\Delta})$ from the saccharification using cellulase $(0.50 \mathrm{~g})$ and xylanase $(0.50 \mathrm{~g})$. Glucose $(\diamond)$ and xylose $(\triangle)$ from the saccharification using only cellulase $(1.0 \mathrm{~g})$.

maximum. Under optimized conditions where the saccharification was performed for the LMAA-pretreated napiergrass $(10.0 \mathrm{~g})$ by a mixture of enzymes, cellulase $(0.50 \mathrm{~g})$ and xylanase $(0.50 \mathrm{~g})$, the yields of glucose and xylose reached $94 \%$ and $68 \%$, respectively (run 7). Moreover, the addition of xylanase shortened the saccharification time of xylan to $168 \mathrm{~h}$, as shown in Figure 1.

\section{SSCF of the LMAA-pretreated napiergrass}

The results of SSCF were listed in Table 2. The ethanol yield was $43 \%$ in the SSCF of non-treated napiergrass using S. cerevisiae, E. coli KO11, cellulase and xylanase, (Table 2, run 1). The LMAA-pretreatment enhanced the ethanol yield (runs 2-3). The amount of napiergrass was optimized to be $3.0 \mathrm{~g}$ from the comparison of ethanol yields in the cases of 2.5 to $4.0 \mathrm{~g}$ (runs $5-7$ ). Maximum ethanol yield was $74 \%$ in SSCF of LMAA-pretreated napiergrass using S. cerevisiae, E. coli KO11, cellulase, and xylanase for $96 \mathrm{~h}$ (run 2). The ethanol yield was not changed even though SSCF time was elongated until $168 \mathrm{~h}$ when the xylose yield reached the maximum yield in saccharification process. In the case of SSCF without S. cerevisiae (run 3), the ethanol yield was $70 \%$. If the glucan $(1.191 \mathrm{~g})$ occurring in the LMAA-pretreated napiergrass $(3 \mathrm{~g})$ is completely turned to ethanol, $676 \mathrm{mg}$ of ethanol will be produced. Ethanol amounts of SSCF in runs 2 and 3 exceeded this value $(676 \mathrm{mg})$, showing that the pentose fermentation apparently occurred. Moreover, the ethanol amount (777 $\mathrm{mg}$, run 2) was comparable to the ethanol amount $(880 \mathrm{mg}$ ) which was ethanol amount when glucose and xylose produced by enzymatic saccharification (Table 1 run 7) would be completely fermented. Therefore, it was suggested that yields of hexose and pentose fermentations were moderately high.

\section{The additive effect of Saccharomyces cerevisiae}

S. cerevisiae is the most commonly used microorganism for industrial ethanol production. However, it cannot utilize xylose for growth and ethanol production. Therefore, it is requisite to use a recombinant species which can ferment pentose. In our SSCF process, S. cerevisiae was used in addition to a recombinant E. coli KO11 for fermentation, since it was found that the SSCF using four components (S. cerevisiae, E. coli KO11, cellulase, and xylanase) proceeded slightly faster than the SSCF without S. cerevisiae.

Figure 3 shows time conversions of ethanol, glucose, and xylose in SSCF. The ethanol yield increased gradually until the yield reached $50 \%$ which was comparable to the SSF yield (55\%) using S. cerevisiae, cellulase and xylanase (Table 2, run 4). At that time, the glucose was completely fermented due to the fast glucose formation 


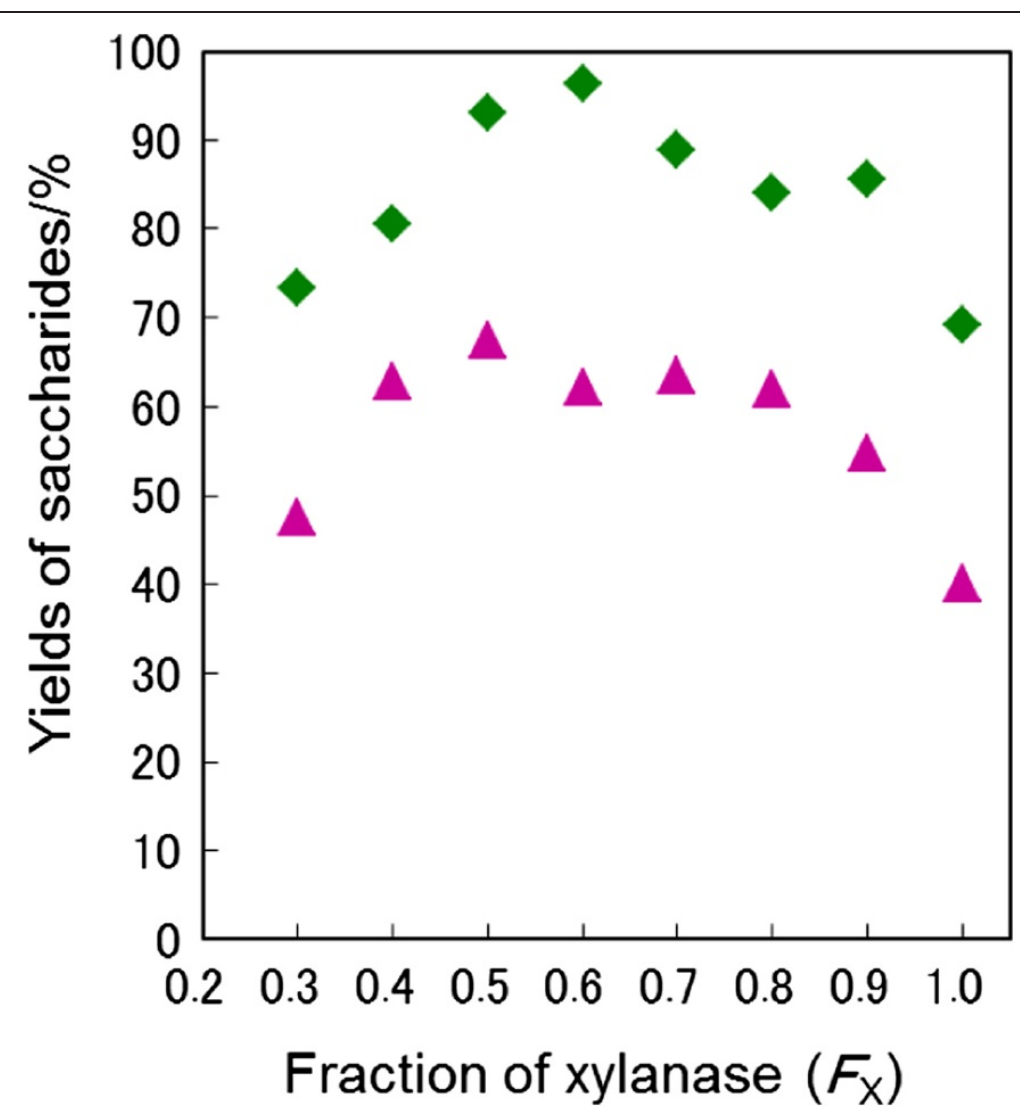

Figure 2 The effects of the fraction of xylanase $\left(F_{X}\right)$ on the yields of glucose $(\boldsymbol{)})$ and xylose $(\boldsymbol{\Delta})$. The saccharification of LMAA-pretreated napiergrass (10.0 g) was performed for $168 \mathrm{~h}$ using a mixed enzyme of cellulase and xylanase.

Table 2 SSCF of LMAA-treated napiergrass ${ }^{a)}$

\begin{tabular}{|c|c|c|c|c|c|c|c|c|c|}
\hline \multirow[t]{2}{*}{ No } & \multicolumn{2}{|c|}{ Napiergrass } & \multirow{2}{*}{$\begin{array}{l}\text { Enzyme/ } \\
\text { mgd) }^{\text {d) }}\end{array}$} & \multirow{2}{*}{$\begin{array}{c}\mathrm{KO11/} \\
\mathrm{mL}^{\mathrm{e})}\end{array}$} & \multirow{2}{*}{$\begin{array}{c}\text { Yeast/ } \\
\mathrm{mL}^{\mathrm{f}}\end{array}$} & \multicolumn{3}{|c|}{ Products/mg (Yield/\%) ${ }^{\mathbf{b})}$} & \multirow{2}{*}{$\begin{array}{c}\text { Ethanol/ } \\
\left.\mathrm{gL}^{-1} \mathrm{~h}\right)\end{array}$} \\
\hline & $\mathrm{PT}^{\mathrm{c})}$ & Weight/g & & & & Xylose & Glucose & Ethanol & \\
\hline 1) & $\mathrm{NO}$ & 3.0 & 300 & 21 & 0.36 & $209 \pm 14(35)$ & $19 \pm 2(2)$ & $353 \pm 31(43)$ & 8.8 \\
\hline 2 & LMAA & 3.0 & 300 & 21 & 0.36 & $73 \pm 25(10)$ & $47 \pm 10(4)$ & $777 \pm 15(74)$ & 19.4 \\
\hline 3 & LMAA & 3.0 & 300 & 21 & 0 & $148 \pm 11(20)$ & $43 \pm 2(3)$ & $731 \pm 12(70)$ & 18.3 \\
\hline $4^{\mathrm{j})}$ & LMAA & 3.0 & 300 & 0 & 0.36 & $473 \pm 43(65)$ & $29 \pm 10(2)$ & $576 \pm 39(55)$ & 14.4 \\
\hline 5 & LMAA & 2.5 & 250 & 21 & 0.36 & $304 \pm 15(50)$ & $37 \pm 6(3)$ & $547 \pm 41(63)$ & 13.7 \\
\hline 6 & LMAA & 3.5 & 350 & 21 & 0.36 & $385 \pm 45(53)$ & $37 \pm 2(3)$ & $719 \pm 13(59)$ & 18.1 \\
\hline 7 & LMAA & 4.0 & 400 & 21 & 0.36 & $438 \pm 37(60)$ & $39 \pm 8(3)$ & $829 \pm 28(60)$ & 21.4 \\
\hline
\end{tabular}

a) SSCF was performed for napiergrass $(3.0-4.0 \mathrm{~g})$ using cellulase $(150-200 \mathrm{mg})$ and xylanase (150-200 mg) in buffer (19 mL), E. coli KO11 (21 ml), and S. cerevisiae $(0.36 \mathrm{~mL})$ at $36^{\circ} \mathrm{C}$ for $96 \mathrm{~h}$. The data were expressed as averages of the experiments at three times.

${ }^{b}$ The maximum amounts of xylose, glucose, and ethanol were $729 \mathrm{mg}, 1323 \mathrm{mg}$, and $1049 \mathrm{mg}$ obtained from $3.0 \mathrm{~g}$ of LMAA-pretreated napiergrass, respectively.

c) Pretreatment (PT). NO: non-treatment. LMAA: a low-moisture anhydrous ammonia pretreatment for four weeks.

d) Weight of total hydrolytic enzyme (cellulase and xylanase) in $\mathrm{mg}$. The fraction $\left(F_{\mathrm{X}}\right)$ of xylanase in the mixture of cellulase and xylanase was 0.50 .

e) Volume of the cell suspension of E. coli KO11 in ml.

${ }^{f}$ Volume of the cell suspension of S. cerevisiae in $\mathrm{mL}$.

${ }^{\mathrm{h})}$ Concentration of ethanol in $\mathrm{g} \mathrm{L}^{-1}$.

i) The maximum amounts of xylose, glucose, and ethanol obtained from non-treated napiergrass (3.0 g) were $576 \mathrm{mg}, 1043 \mathrm{mg}$, and $827 \mathrm{mg}$, respectively.

$\left.{ }^{j}\right)$ The simultaneous saccharification and fermentation (SSF) using cellulase $(150 \mathrm{mg})$ and xylanase $(150 \mathrm{mg})$, and S. cerevisiae $(0.36 \mathrm{~mL})$ at $36^{\circ} \mathrm{C}$ for $96 \mathrm{~h}$. 

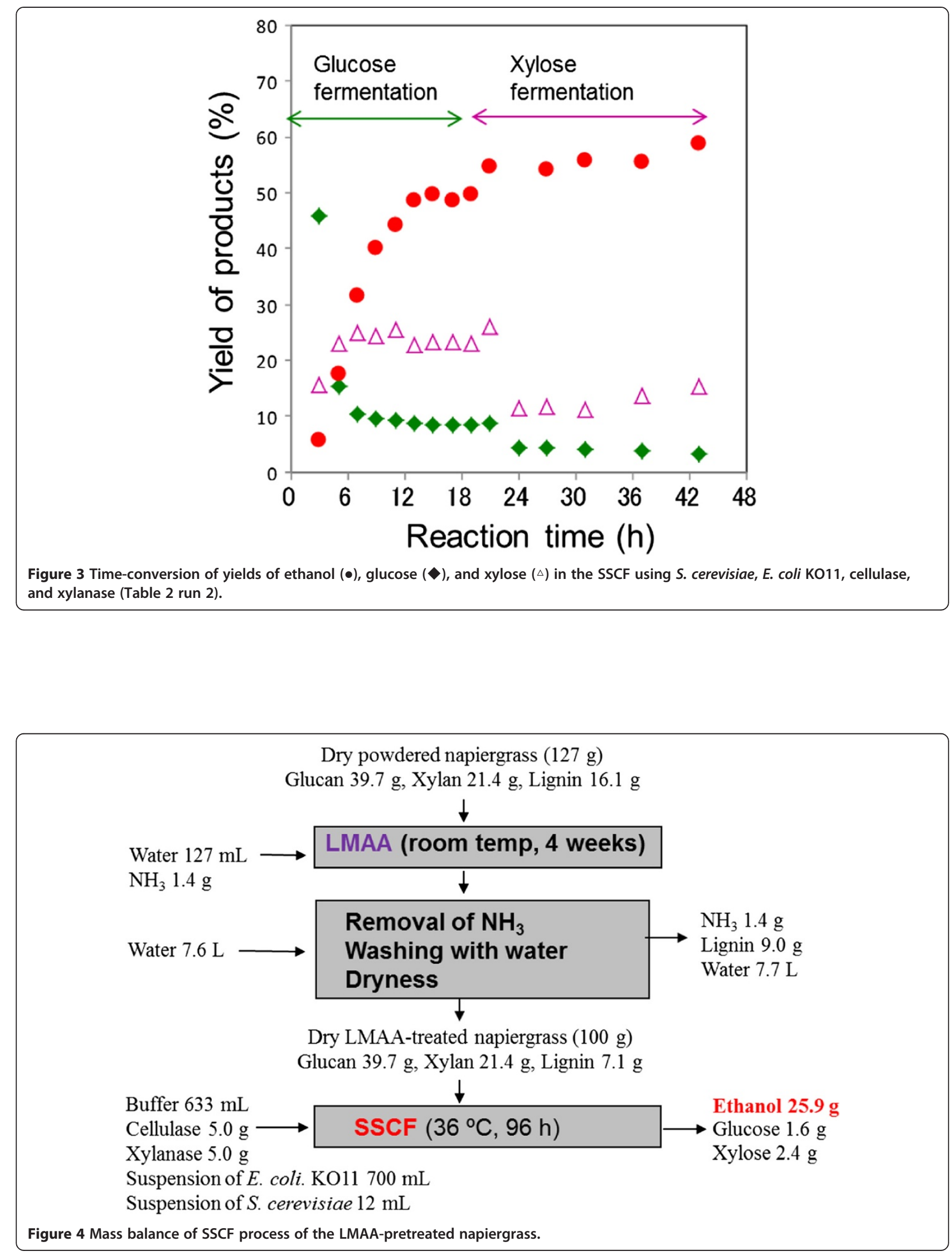
in the saccharification while the xylose was accumulated due to slow fermentation of xylose. After SSCF for $18 \mathrm{~h}$, the xylose fermentation started, resulting in that ethanol yield increased again.

\section{Conclusions}

We have previously examined ethanol formation through a combination of SSF using enzyme and S. cerevisiae with a pentose fermentation using E. coli KO11. The ethanol yields from LMAA-pretreated and non-treated napirgrass were 69\% (Yasuda et al. 2013) and 44\% (Yasuda et al. 2012), respectively. The present SSCF process improved the ethanol yield to $74 \%$. Mass balance of the present SSCF is summarized in Figure 4. Consequently $25.9 \mathrm{~g}$ of ethanol was produced from $100 \mathrm{~g}$ of LMAA-pretreated napiergrass which was obtained from $127 \mathrm{~g}$ of the nontreated powdered napiergrass. Since the SSCF can be performed in one-pot reaction, it can prevent contamination risks of other micro-organism and can construct simple processing procedure. Thus, efficient bio-ethanol production from napiergrass was successfully achieved by the combination of the LMAA-pretreatment with the SSCF process using four components (cellulase, xylanase, Saccharomyces cerevisiae, and E. coli KO11).

\section{Competing interests}

The authors declare that they have no competing interests.

\section{Authors' contributions}

MY conceived experimental idea involving LMAA-pretreatment and SSCF and analyzed experimental data. Also MY prepared the manuscript and revised it. $\mathrm{HN}$ and $\mathrm{KO}$ carried out fermentation process using E. coli KO11. KT carried out LMAA-pretreatment and saccharification processes. Yl developed dwarf type of napiergrass and provided raw material. All authors read and approved the final manuscript.

\section{Acknowledgments}

We sincerely thank Lonnie O. Ingram from the University of Florida for providing the E. coli KO11 strain. This study was done as a part of the project entitled "Research and Development of Catalytic Process for Efficient Conversion of Cellulosic Biomass into Biofuels and Chemicals (2009-2013)" through Special Funds for Education and Research from the Ministry of Education, Culture, Sports, Science, and Technology of Japan.

\section{Author details}

'Department of Applied Chemistry, Faculty of Engineering, University of Miyazaki, Gakuen-Kibanadai Nishi, Miyazaki 889-2192, Japan. ²Department of Animal and Grassland Sciences, Faculty of Agriculture, University of Miyazaki, Gakuen-Kibanadai Nishi, Miyazaki 889-2192, Japan. ${ }^{3}$ Department of Biochemistry and Applied Biosciences, Faculty of Agriculture, University of Miyazaki, 1-1 Gakuen-Kibanadai Nishi, Miyazaki 889-2192, Japan.

Received: 18 May 2014 Accepted: 23 June 2014

Published: 1 July 2014

\section{References}

Brandon SK, Sharma LN, Hawkins GM, Anderson WF, Chambliss CK, DoranPeterson J (2011) Ethanol and co-product generation from pressurized batch hot water pretreated T85 bermudagrass and Merkeron napiergrass using recombinant Escherichia coli as biocatalyst. Biomass Bioenergy 35:3667-3673

Galbe M, Zacchi G (2007) Pretreatment of lignocellulosic materials for efficient bioethanol production. Adv Biochem Eng Biotechnol 108:41-65

Hanna WW, Sollenberger LE (2007) Tropical and Subtropical Grasses. In: Barnes RF (ed) Forages, vol II, 6th edn. Blackwell Pub, lowa USA, pp 245-255
Ishii Y, Yamaguchi N, Idota S (2005a) Dry matter production and in vitro dry matter digestibility of tillers among napiergrass (Pennisetum purpureum Schumach) varieties. Grassl Sci 51:153-163

Ishii Y, Mukhtar M, Idota S, Fukuyama K (2005b) Rotational grazing system for beef cows on dwarf napiergrass pasture oversown with Italian ryegrass for 2 years after establishment. Grassl Sci 51:209-220

Ishii Y, Hamano K, Kang DJ, Rengsirikul K, Idota S, Fukuyama K, Nishiwaki A (2013) $\mathrm{C}_{4}$-Napier grass cultivation for cadmium phytoremediation activity and organic livestock farming in Kyushu, Japan. J Agric Sci Techn A 3:321-330

Jin M, Gunawan C, Balan V, Lau MW, Dale BE (2012a) Simultaneous saccharification and co-fermentation (SSF) of AFEX ${ }^{\mathrm{TM}}$ pretreated corn stover for ethanol production using commercial enzymes and Saccharimyces cerevisiae 424A (LNH-ST). Bioresour Technol 110:587-594

Jin M, Gunawan C, Balan V, Yu X, Dale BE (2012b) Continuous SSF and AFEX ${ }^{\text {TM }}$ pretreated corn stover for enhanced ethanol productivity using commercial enzymes and Saccharimyces cerevisiae 424A (LNH-ST). Biotechnol Bioengineer 110:1302-1311

Khairani L, Ishii Y, Idota S, Utamy RF, Nishiwaki A (2013) Variation in growth attributes, dry matter yield and quality among 6 genotypes of Napier grass used for biomass in year of establishment in southern Kyushu. Asian J Agric Res 7:15-25

Kitamikado T, Toyama N (1962) An assay method for cellulase based on the breakdown of filter paper. Hakkoukougakuzasshi 40:85-88

Matsushika A, Inoue H, Kodaki T, Sawayama S (2009) Ethanol production from xylose in engineered Saccharomyces cerevisiae strains: current state and perspectives. Appl Micorobiol Biotechnol 84:37-53

Mukhtar M, Ishii Y, Tudsri S, Idota S, Sonoda T (2003) Dry matter productivity and overwintering ability in the dwarf and normal napiergrasses as affected by the planting density and cutting frequency. Plant Prod Sci 6:65-73

Ohgren K, Bengtsson O, Gorwa-Grauslund MF, Galbe M, Hahn-Hagerdal B, Zacchi G (2006) Simultaneous saccharification and co-fermentation of glucose and xylose in steam-pretreated corn stover at high fiber content with Saccharomyces cerevisiae TMB3400. J Biotechnol 126:488-498

Ohta K, Alterthum F, Ingram LO (1990) Effects of environmental conditions on xylose fermentation by recombinant Escherichia coli. Appl Environ Microbiol 56:463-465

Ohta K, Beall DS, Mejia JP, Shanmugam KT, Ingram LO (1991) Genetic improvement of Escherichia coli for ethanol production: chromosomal integration of Zymomonas mobilis genes encoding pyruvate decarboxylase and alcohol dehydrogenase II. Appl Environ Microbiol 57:893-900

Rengsirikul K, Ishii Y, Kangvansaichol K, Pripanapong P, Sripichitt P, Punsuvon V, Vaithanomsat P, Nakamanee G, Tudsri S (2011) Effects of inter-cutting interval on biomass yield, growth components and chemical composition of napiergrass (Pennisetum purpureum Schumach) cultivars as bioenergy crops in Thailand. Grassl Sci 57:135-141

Rengsirikul K, Ishii $Y$, Kangvansaichol K, Sripichitt $P$, Punsuvon $V$, Vaithanomsat $P$, Nakamanee G, Tudsri S (2013) Biomass yield, chemical composition and potential ethanol yields of 8 cultivars of napiergrass (Pennisetum purpureum Schumach) harvested 3-monthly in central Thailand. J Sustainable Bioenergy Systems 3:107-112

Shiragami T, Tomo T, Tsumagari H, Ishii Y, Yasuda M (2012) Hydrogen evolution from napiergrass by the combination of biological treatment and a Pt-loaded $\mathrm{TiO}_{2}$-photocatalytic reaction. Catalyst 2:56-67

Sluiter A, Hames B, Ruiz R, Scarlata C, Sluiter J, Templaton D, Crocker D (2010) Determination of structural carbohydrates and lignin in biomass, Technical Report NREL/TP-510-42618, National Renewable Energy Laboratory, Golden, CO

Su R, Ma Y, Qi W, Zhang M, Wang F, Du R, Yang J, Zhang M, He Z (2012) Ethanol production from high-solid SSCF of alkaline-pretreated corncob using recombinant Zymomonas mobilis CP4. Bioeng Res 6:292-299

Taherzadeh MJ, Karimi K (2007) Enzyme-based hydrolysis processes for ethanol from lignocelluosic materials: a review. BioResources 2:707-728

Underwood SA, Buszko ML, Shanmugam KT, Ingram LO (2002) Flux through citrate synthase limits the growth of ethanologenic Escherichia coli KO11 during xylose fermentation. Appl Environ Microbiol 68:1071-1081

Utamy RF, Ishii Y, Idota S, Harada N, Fukuyama K (2011) Adaptability of dwarf napiergrass under cut-and-carry and grazing systems for smallholder beef farmers in southern Kyushu, Japan. J Warm Regional Society of Animal Science Jpn 54:65-76

Yasuda M, Miura A, Yuki R, Nakamura Y, Shiragami T, Ishii Y, Yokoi H (2011) The effect of $\mathrm{TiO}_{2}$-photocatalytic pretreatment on the biological production of ethanol from lignocelluloses. J Photochem Photobiol A Chem 220:195-199 

with Escherichia coli KO11. J Biosci Bioeng 114:188-192

Yasuda M, Takeo K, Nagai H, Uto T, Yui T, Matsumoto T, Ishii Y, Ohta K (2013) Enhancement of ethanol production from napiergrass (Pennisetum

purpureum Schumach) by a low-moisture anhydrous ammonia pretreatment. J Sustainable Bioenergy Systems 3:179-185

Yoo CG, Nghiem NP, Hicks KB, Kim TH (2011) Pretreatment of corn stover by low moisture anhydrous ammonia (LMAA) process. Bioresour Technol 102:10028-10034

doi:10.1186/2193-1801-3-333

Cite this article as: Yasuda et al:: Bio-ethanol production through simultaneous saccharification and co-fermentation (SSCF) of a low-moisture anhydrous ammonia (LMAA)-pretreated napiegrass (Pennisetum purpureum Schumach). SpringerPlus 2014 3:333.

\section{Submit your manuscript to a SpringerOpen ${ }^{\circ}$} journal and benefit from:

- Convenient online submission

- Rigorous peer review

- Immediate publication on acceptance

Open access: articles freely available online

- High visibility within the field

- Retaining the copyright to your article 